
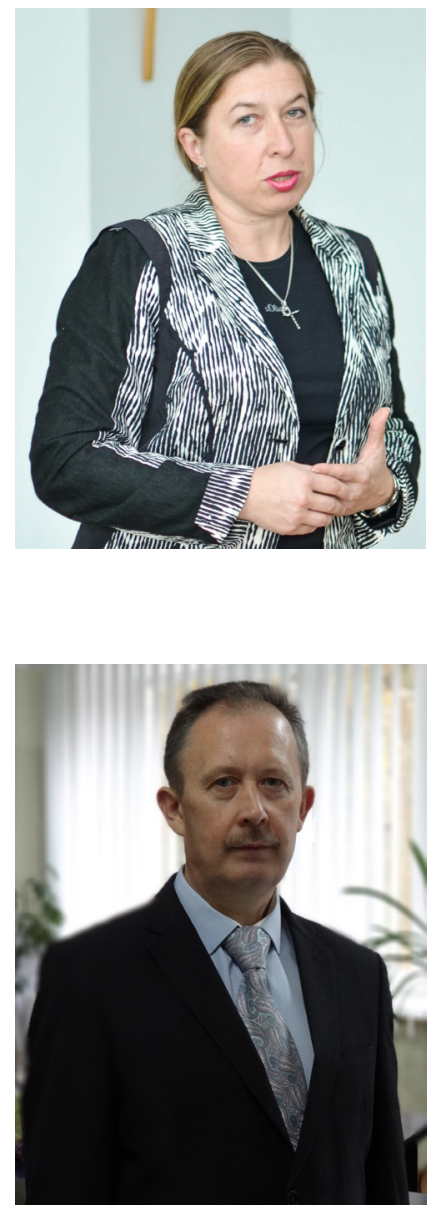

\section{Оксана Кондур,}

доктор педагогічних наук, доцент, декан Педагогічного факультету, ДВНЗ «Прикарпатський національний університет імені Василя Стефаника», (м. Івано-Франківськ, Україна)

\section{Oksana Kondur,}

Doctor of pedagogical sciences, Associate Professor, Dean of the Teacher's Training Department, Vasyl Stefanyk Precarpathian National University (Ivano-Frankivsk, Ukraine) oxikon13@gmail.com ORCID: 0000-0001-9342-1127

\section{Валерій Ратушняк,} кандидат фізико-математичних наук, викладач інформатики, Коломийський економіко-правовий коледж (м. Коломия, Україна)

\author{
Valerii Ratushniak, \\ Candidate of Physics and Mathematics Sciences, \\ Teacher of computer science, \\ Kolomyja College of Economics and Law \\ (Kolomyja, Ukraine) \\ rval@gmail.com
}

\title{
СУЧАСНІ ТЕХНОЛОГІЇ КОНТРОЛЮ ЗНАНЬ ТА ВМІНЬ ЗДОБУВАЧІВ ОСВІТИ
}

Анотація. У статті проведено аналіз сучасного тлумачення поняття «контроль знань». До основних функцій контролю знань і вмінь здобувачів освіти належать навчальна, діагностична, стимулювальна, виховна функція оцінки. Надзвичайне значення має управлінська функція. Оскільки, окрім перевірки рівня засвоєння навчального матеріалу, контроль важливий для ухвалення рішень з оптимізації освітнього процесу.

Види контролю знань та вмінь класифікують залежно від місця в процесі досягнення дидактичної мети освітньої діяльності. Для збільшення ефективності навчання варто практикувати різні способи організації контролю. Адже правильна та раціональна організація контролю знань та вмінь сприяє вчасному виявленню прогалин у знаннях і вміннях здобувачів освіти, визначенню рівня готовності їх до засвоєння нового матеріалу, формуванню в них навичок самоконтролю.

До найефективніших методів контролю знань належать тестові форми. За сучасного стану розвитку технологій їх застосовують з використанням тестових оболонок стаціонарного типу або на онлайн-платформах.

Набувають поширення хмарні сервіси, які дозволяють залучати дистанційно широкі аудиторії та проводити оцінювання рівня знань і вмінь у реальному часовому режимі. Такі засоби рекомендуємо використовувати 3 урахуванням особливостей як фахових, так і регіональних (наприклад, для студентів нестаціонарної форми навчання 3 віддалених гірських регіонів).

Ключові слова: сучасні технології, контроль, контроль знань, контроль навичок, ресурси, заклад вищої освіти.

\section{THE MODERN TECHNOLOGIES FOR THE CONTROL OF KNOWLEDGE AND SKILLS OF EDUCATION RECIPIENTS}

Abstract. The article analyzes the modern interpretation of the concept of "knowledge control". The main functions of control of knowledge and skills of the educational recipients are educational, diagnostic, stimulating, educational functions, function of assessment. The management function is of paramount importance. In addition to controlling the level of learning, it is important to make decisions about optimizing the educational process. 
Types of control knowledge and skills are classified according to place in the process of achieving the didactic goal of educational activities.To increase the effectiveness of training, it is necessary to practice different ways of organizing control. Because proper and rational organization of control of knowledge and skills contributes to identifying gaps in the knowledge and skills of the learners, determining their level of readiness to learn new material. Control also forms students' self-control skills.

Testing is an effective way to control knowledge. The current state of technology development tests are set using test shells of the stationary type or on online platforms.

Cloud services are spreading. They allow you to reach remote audiences and evaluate real-time knowledge and skills.

We recommend using cloud technologies for professional and regional specialties (for example, for students of nonstationary form of study from remote mountain regions).

Keywords: modern technologies, knowledge control, skills control, online resources, higher education institution.

\section{ВСТУП}

Постановка проблеми. На сучасному етапі побудова та управління освітньо-виховним процесом неможливі без використанням новітніх інформаційних, інтерактивних і мультимедійних технологій. Застосування інноваційних технологій у процесі проведення контролю знань студентів порівняно з традиційними формами контролю здійснюється оперативніше та ефективніше. Особливо важливе застосування інформаційних технологій під час дистанційного контролю набутих знань та вмінь здобувачів освіти, які живуть/працюють віддалено від закладу вищої освіти. На сьогодні є багато цифрових та онлайн-ресурсів, які рекомендуємо застосовувати.

Аналіз останніх досліджень і публікацій. Поняття «контроль знань» трактується науковцями як «спосіб перевірки навчання і діяльності педагогічних кадрів» (С.У. Гончаренко (Гончаренко С., 2012, с. 182)), «перевірка чогось, принцип зворотного зв'язку; має освітнє, виховне і розвиваюче значення» (С.П. Максимюк, (Максимюк С., 2005, с. 182)); «контроль за навчанням - постійний нагляд, спостереження і перевірка успішності знань учнів з метою отримання об'єктивної інформації про навчально-виховний процес» (Н. П. Волкова (Волкова Н., 2007, с. 406)); як педагогічне поняття, що означає «це усвідомлене, планомірне спостереження та фіксацію вербальних і практичних дій вихованців з метою з'ясування рівня набуття ними соціального досвіду, опанування програмного матеріалу, оволодіння теоретичними і практичними знаннями, навичками й уміннями та формування в них певних особистісних і професійних рис» (В.В. Ягупов (Ягупов В, 2003, с. 182)); «установлення зворотного зв'язку, тобто отримання викладачем інформації про результати навчальної діяльності студентів і прийняття рішення про характер наступної діяльності в залежності від цієї інформації» (В.В. Кудіна та ін. (Кудіна В., Соловей М., \& Спіцин Є., с. 182)); «контроль знань, умінь та навичок - це перевірка результативності процесу вирішення навчально-виховних завдань, кожне з яких характеризується дидактичною завершеністю» (М. М. Фіцула (Фіцула М., 2002, с. 188)). На думку А. І. Кузьмінського (Кузьмінський А., 2012), термін «контроль знань» часто ототожнюють чи замінюють терміном «перевірка знань». Проте «контроль означає не тільки перевірку, а й оцінювання результатів навчання», що є «складовими єдиного процесу, без яких неможливо уявити педагогічну взаємодію» між вчителем і здобувачем освіти.

\section{МЕТА І ЗАВДАННЯ ДОСЛІДЖЕННЯ}

Мета статті полягає в систематизації видів, форм організації контролю знань та навичок здобувачів освіти та описі можливостей оптимізації цієї ланки освітнього процесу за допомогою сучасних інформаційних технологій.

\section{РЕЗУЛЬТАТИ ДОСЛІДЖЕННЯ}

у будь-якій освітній системі найосновніше - це вчитися. Проте освіта не зводиться тільки до отримання знань і навичок. Упродовж навчального періоду відбувається формування загальних та фахових компетентностей у здобувачів освіти. При цьому важлива роль контролю рівня набутих знань, навичок, умінь. До основних функції контролю належать навчальна, діагностична, стимулювальна, виховна, функція оцінки (рис.1).

Освітня функція: контроль засвоєння знань - одна з передумов забезпечення дієвості й ефективності освітнього процесу; виховна функція: контроль сприяє самоорганізації здобувачів освіти, виховує в них відповідальність, дисциплінованість, наполегливість, працьовитість (Бондар В., 2005); діагностична функція: контроль знань виявляє прогалини в знаннях, причини їх виникнення та сприяє покращенню освітньої діяльності загалом; стимулювальна функція: потреба індивіда в усвідомленні результативності навчання, самореалізації; оцінювальна функція: бажання здобувача освіти отримати кількісні показники своєї освітньої діяльності, порівняння з успіхами інших, стимул до вдосконалення. Таким чином, педагогічна оцінка формує самосвідомість здобувача освіти, вимогливість до себе та інших. У освітньо-виховному процесі всі функції тісно взаємопов'язані та переплетені.

3 точки зору теорії менеджменту контроль виконує також функції управління, корегування, планування. Функція управління реалізується керівництвом освітнього закладу в організації освітнього процесу і взаємодії його учасників. Функція корегування носить бінарний характер, оскільки може виражатись в удосконаленні змісту освіти та в трансформації методів і прийомів контролю результатів освітньої діяльності з метою досягнення її адекватності. Функція планування $є$ наслідком двох попередніх задля досягнення ефективності в плануванні подачі та засвоєнні знань, прийомів контролю результативності всіх учасників освітнього процесу.

Залежно від місця в процесі досягнення дидактичної мети види навчального контролю поділяють на: попередній, який проводять перед вивченням нового навчального матеріалу і поєднують з компенсаційним навчанням, яке спрямоване на усунення прогалин у знаннях, уміннях здобувачів освіти; поточний контроль здійснюють у процесі вивчення кожної теми чи кожного заняття і в такий спосіб реалізують навчальні та стимулювальні цілі; тематичний контроль відбувається після вивчення теми, розділу, модуля програми; підсумковий проводиться наприкінці 
структурного періоду навчального процесу (чверть, семестр, півріччя, рік, підсумкова атестація на завершення всього циклу навчання).

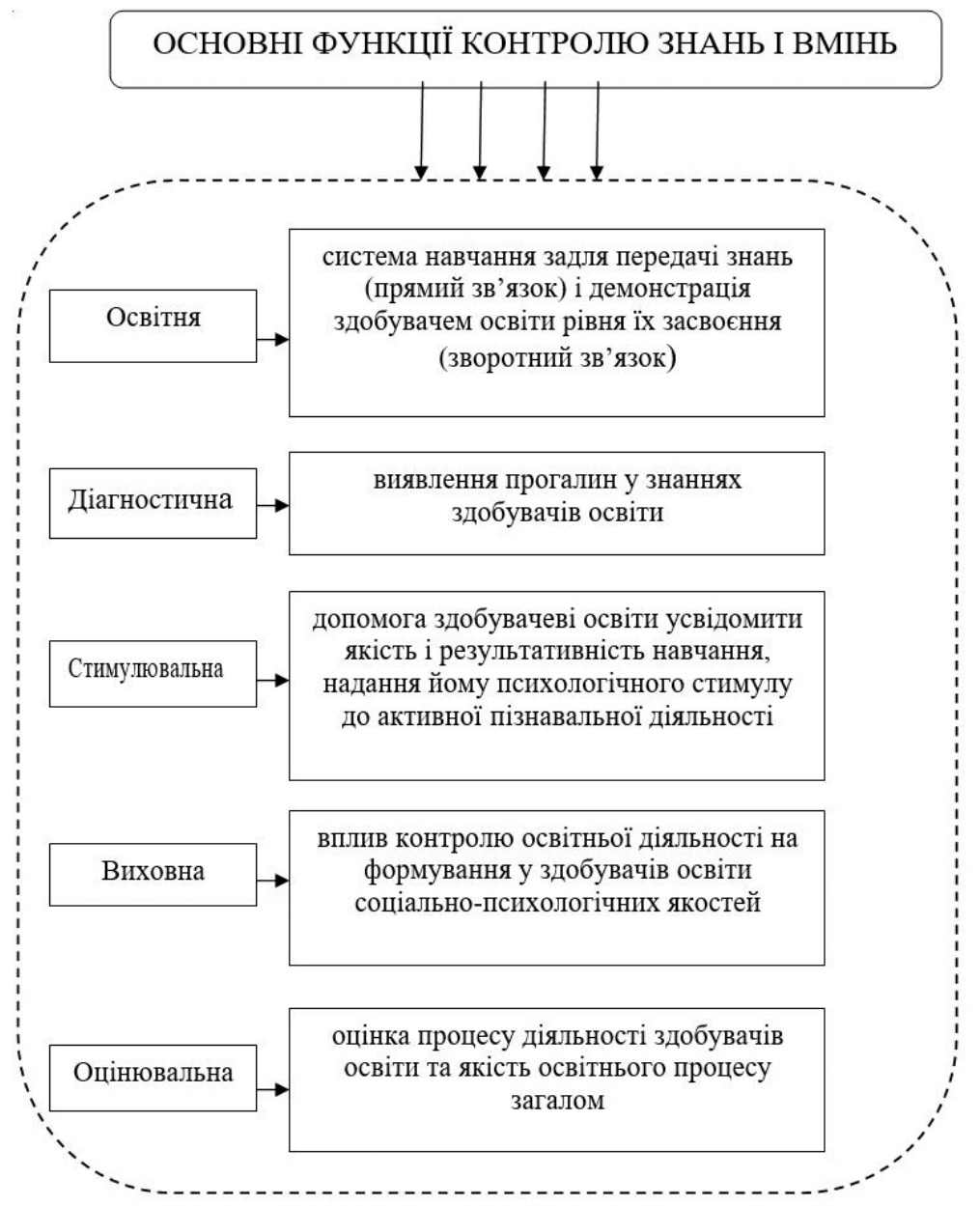

Рис. 1. Функції контролю знань та вмінь здобувачів освіти

Правильна та раціональна організація контролю знань та вмінь сприяє вчасному виявленню прогалин у знаннях і вміннях здобувачів освіти, визначенню рівня готовності їх до засвоєння нового матеріалу, формуванню в них навичок самоперевірки і самоконтролю. Найпоширеніші форми організації за навчальною діяльністю здобувачів освіти наведено на рис.2.

У процесі глобалізації знань та вмінь, посиленні міжнародних взаємодій та зв'язків важливо не тільки формувати в здобувачів освіти основи знань та навичок глобалізації, але й оновлювати форми та види їх контролю. Як стверджує О. Гаврилюк, «основними сучасними технологіями контролю знань, умінь та навичок у закладі вищої освіти є: тестова; модульно-рейтингова; кредитно-трансферна; програмова» (Гаврилюк О., 2018, с. 178).

Із розвитком технологій удосконалюються методи контролю знань і навичок. Серед найоптимальніших методів контролю з точки зору обробки отриманої інформації є тестовий контроль. Ефективність такого виду контролю досягається завдяки формуванню тестів із завдань різного типу: закритих, відкритих, з відповідями у вигляді відображення відповідностей між запитаннями та варіантами відповідей; відтворення правильної послідовності, на порівняння протилежностей; вибір неправильної відповіді серед сукупності правильних, фасетні тестові завдання закритої форми.

Залежно від можливості використання інформаційних технологій педагогічне тестування поділяють на бланкове і комп'ютерне.

Тестова форма контролю набула широкого використання в системах дистанційного навчання. Найпоширенішою є безкоштовна тестова система Moodle (Modular Object-Oriented Dynamic Learning Environment). Нею послуговуються понад сотні країн світу. Ця система спроектована відповідно до сучасних освітніх вимог та орієнтована на методи активного навчання. У цій системі можна використовувати тестові завдання різного типу. Перевага системи Мооdle у формуванні портфоліо кожного здобувача освіти, у якому містяться всі виконані ним роботи, усі оцінки, наявні коментарі викладачів, повідомлення в чатах/форумах. Система дозволяє вести електронний журнал.

Сучасні можливості дають змогу застосовувати дистанційний контроль знань та вмінь здобувачів освіти за допомогою онлайн-платформ, які можна завантажувати навіть на мобільні пристрої. 


\begin{tabular}{|c|c|}
\hline фронтальний & $\begin{array}{l}\text { - задається питання до всіх з метою залучення до } \\
\text { обговорення } \\
\text { • експрес-контроль значної частини групи (класу) }\end{array}$ \\
\hline груповий & $\begin{array}{l}\text { - підсумковий контроль всієї групи чи частини } \\
\text { • задається питання/завдання окремій групі }\end{array}$ \\
\hline індивідуальний & $\begin{array}{l}\text { - для ознайомлення з рівнем начальних чи } \\
\text { практичних досягнень окремого здобувача освіти }\end{array}$ \\
\hline комбінований & $\begin{array}{l}\text { • поєднання фронтального, ідивідуального та } \\
\text { групового }\end{array}$ \\
\hline самоконтроль & $\begin{array}{l}\text { - здобувач освіти самостійно визначає свій рівень } \\
\text { оволодіння знаннями і навичками }\end{array}$ \\
\hline взаємоконтроль & $\begin{array}{l}\text { - контроль та оцінювання з боку інших здобувачів } \\
\text { освіти, відповідальність за оцінювання колег по } \\
\text { навчанню }\end{array}$ \\
\hline
\end{tabular}

\section{Рис. 2. Форми організації контролю за навчальною діяльністю}

Схема використання інформаційних та комунікаційних технологій є визначальним чинником набуття знань та навичок серед молоді відділених (у тому числі гірських) регіонів за умов нестаціонарної форми навчання чи дуальної освіти. Для надання освітніх послуг віддалено можна використовувати хмарні сервіси. Зокрема до таких відноситься Cisco WebEx, завдяки якому проводять онлайн-конференції з аудіо, відеозв'язком і інструментами спільної роботи над документами (завданнями).

Використання в освітній сфері хмарних сервісів Cisco WebEx уможливить: дистанційно демонструвати нові знання; проводити семінари та консультації здобувачів освіти (WebEx Training Center), які перебувають віддалено від закладу вищої освіти, причому одночасно кількох з різних регіонів. При цьому учасники такого онлайн-сеансу одержують спільний доступ до робочого столу, клавіатури і миші, документам MS Office, іншим додаткам, можуть обмінюватись миттєвими повідомленнями, голосувати чи використовувати метод мозкового штурму. За допомогою цього ресурсу можна створювати повноцінні навчальні відеоролики за рахунок можливості запису всього, що відбувається під час аудиторного заняття (лекції, семінару, практичного чи лабораторного заняття).

За допомогою сервісу Collaboration Meeting Room можна підключатись до обговорення не тільки з персонального комп'ютера, мобільного пристрою, але і відео терміналів. Сервіс WebEx Meeting Center можна застосувати для спільної роботи над документами в режимі реального часу, тобто для проведення практичних чи семінарських занять з трансляцією аудіо та відео. Сервіс WebEx Event Center дає можливість проведення лекцій з демонстрацією матеріалів в режимі онлайн для аудиторії до 3000 учасників.

Можливості хмарних сервісів Cisco WebEx $€$ неоціненними при контролю знань і навичок, які потребують демонстрації, зокрема - для здобувачів освіти мистецьких і педагогічних спеціальностей, наприклад з виконавської майстерності, малювання, педагогічної майстерності та ін.

Застосування технологій WebEx у Прикарпатському національному університеті імені Василя Стефаника отримало схвальні відгуки викладачів та здобувачів освіти.

\section{ВИСНОВКИ ТА ПЕРСПЕКТИВИ ПОДАЛЬШИХ ДОСЛІДЖЕНЬ}

Аналіз науково-методичної літератури демонструє постійну актуальність контролю знань та вмінь здобувачів освіти з точки зору діагностичної функції, управлінської та самовдосконалення. Інновації в освіті та активне впровадження інформаційних технологій актуалізують проблему контролю знань і навичок здобувачів освіти за умов гірського середовища. Для забезпечення якості освіти важливо до контролю освітньо-практичного рівня здобувачів освіти залучати стейкхолдерів з числа працедавців.

Бондар, В. І. (2005). Дидактика. Київ: Либідь.

\section{СПИСОК ВИКОРИСТАНИХ ДЖЕРЕЛ}

Волкова, Н. П. (2007). Педагогіка: Навч. посіб. Вид. 2-ге, перероб., доп. Київ: Академвидав.

Гаврилюк, О. (2018). Сучасні технології контролю знань студентів з англійської мови в закладі вищої освіти. Педагогічні науки: теорія, історія, інноваційні технології, 7 (81), 174-184.

Гончаренко, С. У. (2012). Педагогічні закони, закономірності, принципи. Сучасне тлумачення. Рівне: Волинські обереги.

Кузьмінський, А. І. (2012). Педагогіка вищої школи: навч. посіб. Київ: Знання.

Кудіна, В. В., Соловей, М. І., \& Спіцин, Є. С. (2007). Педагогіка вищої школи. 2-ге вид., допов. і переробл. Київ: Ленвіт.

Максимюк, С. П. (2005). Педагогіка: Навчальний посібник. Київ: Кондор.

Фіцула, М. М. (2002). Педагогіка: Навчальний посібник для студентів вищих педагогічних закладів освіти. Київ: Видавничий центр «Академія».

Ягупов, В. В. (2003). Педагогіка: навч. посібник. Київ : Либідь. 


\section{REFERENCES}

Bondar, V. I. (2005). Dydaktyka. Kyiv: Lybid.

Volkova, N. P. (2007). Pedahohika: Navch. posib. Kyiv: Akademvydav.

Havryliuk, O. (2018). Suchasni tekhnolohii kontroliu znan studentiv z anhliiskoi movy v zakladi vyshchoi osvity. Pedahohichni nauky: teoriia, istoriia, innovatsiini tekhnolohii, 7 (81), 174-184.

Honcharenko, S. U. (2012). Pedahohichni zakony, zakonomirnosti, pryntsypy. Suchasne tlumachennia. Rivne: Volynski oberehy.

Kuzminskyi, A. I. (2012). Pedahohika vyshchoi shkoly: navch. posib. Kyiv: Znannia.

Kudina, V. V., Solovei, M. I., \& Spitsyn, Ye. S. (2007). Pedahohika vyshchoi shkoly. Kyiv: Lenvit.

Maksymiuk, S. P. (2005). Pedahohika: Navchalnyi posibnyk. Kyiv: Kondor.

Fitsula, M. M. (2002). Pedahohika: Navchalnyi posibnyk dlia studentiv vyshchykh pedahohichnykh zakladiv osvity. Kyiv: Vydavnychyi tsentr «Akademiia».

lahupov, V. V. (2003). Pedahohika: navch. posibnyk. Kyiv : Lybid.

Статтю подано до редколегії 02.09.2019 р.

Рекомендовано до друку 21.09.2019 p. 